\title{
CONSTRUCTION AND PERFORMANCE EVALUATION OF A HYDROPONIC UNIT FOR BARLEY GREEN FOODER PRODUCTION
}

\author{
Yasser S.M. Abd El-Rahman ${ }^{1 *}$, M.M. Morad ${ }^{2}$, E.H. El- Hanafy ${ }^{1}$ and Mona M. Abdel-Aziz ${ }^{2}$ \\ 1. Agric. Eng. Dept., Technol. and Dev. Fac., Zagazig Univ., Egypt \\ 2. Agric. Eng. Dept., Fac. Agric., Zagazig Univ., Egypt
}

Received: 28/2/2017 ; Accepted: 30/3/2017

\begin{abstract}
The objectives of the present study were to construct and evaluate the performance of a hydroponic unit for intensive barley green fodder production. The constructed hydroponic system included lighting unit to provide plants with its lighting requirement, cooling and air conditioning unit to conserve the appropriate microclimate conditions to propagate a healthy plants and aeration and $\mathrm{CO}_{2}$ proportioning unit to enhance the root-zone media with its air balance to achieve the plant stress. The performance of the constructed hydroponic unit was studied under some different technical parameters (growing period, aeration rate, with and without nutrient solution addition and with and without $\mathrm{CO}_{2}$ injection). The performance of the constructed hydroponic unit was evaluated in terms of total yield, yield quality, water use efficiency, energy requirements, operational cost and net profit. The experimental results reveal that total yield $(4646.4 \mathrm{~kg} /$ period), plant moisture content $(92.13 \%)$, water use efficiency $(156.028 \mathrm{~g} / \mathrm{l})$ and net profit $(8256 \mathrm{LE} /$ period) were in the optimum region under conditions of 8.0 days growing period, $2 \mathrm{hr}$./day aeration rate, with both nutrient solution addition and $\mathrm{CO}_{2}$ injection. While the protein percentage $(18.29 \%)$ was optimum under conditions of 5.0 days growing period, $1 \mathrm{hr}$./day aeration rate, with both nutrient solution addition and $\mathrm{CO}_{2}$ injection. Meanwhile dry matter (21.12\%) was optimum under conditions of 5.0 days growing period, $2 \mathrm{hr}$./day aeration rate, without neither nutrient solution addition nor $\mathrm{CO}_{2}$ injection.
\end{abstract}

Key words: Hydroponic, barley, aeration, protein.

\section{INTRODUCTION}

Animal production and its industrial investment are overwhelmed with various problems due to the insufficient animal feeding requirements and the competition with the human crop requirements. Therefore, about third of the total cultivated area of the world covered with the animal feeding crops. In this regard, efforts have to be carried out to develop new techniques to face this competition such as hydroponics fodder productions.

Availability of appropriate feed prices and one of the main reasons for the increase in animal production in recent years, tasked senior and junior educators to lack of fodder and high cost. For this it was necessary to search for

\footnotetext{
* Corresponding author: Tel. : + 201221490681

E-mail address: yassersalah555@yahoo.com
}

alternatives to traditional feed and as a result of research experts to reach the production of feed barley cultivar that does not need soil or fertilizer or labor-intensive. At the same time characterized by high productivity and high nutritional value. Hydroponic Fodder (HF) can overcome this problem where the plants grow in the nutrient solution without using any growing media. It did not need any disinfection as well as it had an enormous latent potential for fodder production under conditions of arid and semiarid areas to reduce the water consumption of fodder plants to very low levels. In addition, HF had a great potential for fodder production in areas where soil has a pest and disease problems. Barley fodder systems are the focus of the present analysis. 
Seymour (1993) stated that Nutrient Film Technique (NFT) consists of a flat-bottomed channel or gully in which a thin film of nutrient is re-circulated through the bare roots of the plant. He also noticed that the important aspect of NFT is to ensure that sufficient oxygen is available to the plant. This may require either agitating of the nutrient within the tank or allowing air to reach the nutrient solution within the channels. He also found that production advantages are achievable under NFT systems but require vigilant management along with high quality equipment and good system design. Jensen (1999) reported that a hydroponics or soilless culture is the production of crops isolated from the soil, either with or without a medium, with their total water and nutrient requirements supplied by the system. Cader (2002) stated that hydroponic fodder is essentially the germination of a seed (such as malt barley or oats) and sprouted into a high quality, highly nutritious, disease free animal food. This process takes place in a very versatile and intensive hydroponic growing unit where only water and nutrients are used to produce a grass and root combination that is very lush and high in nutrients. This green fodder is extremely high in protein and metabolisable energy, which is highly digestible by most animals. Wang et al. (2002) stated that several strategies have been suggested to improve the productivity of water, among which is better management of the water resource. Hydroponics growing techniques improve water use efficiency by restricting water loss. Morgan et al. (2002) used hydroponic fodder technique and found that the increases in protein are "due partly to the absorption of nitrogen from the nutrients solution and to the concentration of nitrogenous compounds in a reduced mass of dry matter. Rotar (2004) found that hydroponic fodder technique can be used to produce fodder in very short periods (7-10 days) and it has been proven efficient both financially and environmentally .

A range of cereals can be utilized for fodder production, including barley, oats, wheat and maize. The most commonly used cereal grain is barley.
Therefore, the aims of the present study were to:

- Construct a hydroponic unit for green fodder production.

- Improve the performance of the hydroponic unit by studying some technical parameters affecting its efficiency (growing period, aeration rate, nutrient solution addition and $\mathrm{CO}_{2}$ injection).

- Evaluate the constructed hydroponic unit economically.

\section{MATERIALS AND METHODS}

The main experiments were carried out in Bahtat Village, Abu Hammed, Sharkia Governorate, Egypt to construct and evaluate the performance of hydroponic barley unit for animal fodder production.

Experimental layouts and procedures mechanisms had been described in Fig. 1 the experimental layouts included lighting system to provide the growing plants with its lighting requirements, cooling and air conditioning system to conserve the appropriate microclimate conditional to propagate a healthy plants, $\mathrm{CO}_{2}$ injection system, aeration system to enhance the root-zone media with its air balance and requirements to avoid the plant stress.

\section{Materials}

\section{The Constructed Hydroponic System}

The constructed hydroponic unit consisted of the following parts: frame, growth trays and aeration, lighting, cooling, irrigation, supernatant collection and control units, as presented in Fig. 2.

\section{Frame}

The frame was constructed of sandwich panel, which consists of two sheets of galvanized electrostatic steel plates, including insulating material (foam) with $5.0 \mathrm{~cm}$ thickness, $4.0 \mathrm{~m}$ width, $4.0 \mathrm{~m}$ length and $3.5 \mathrm{~m}$ height.

\section{Plant growth unit}

The plant growth unit consisted of trays. Each tray was made of white polypropylene material with dimensions of $30 \times 70 \times 4 \mathrm{~cm}$. The bottom of trays was perforated with $3 \mathrm{~mm}$ holes diameter and spacing of $70 \times 40 \mathrm{~mm}$. 
Zagazig J. Agric. Res., Vol. 44 No. (3) 2017

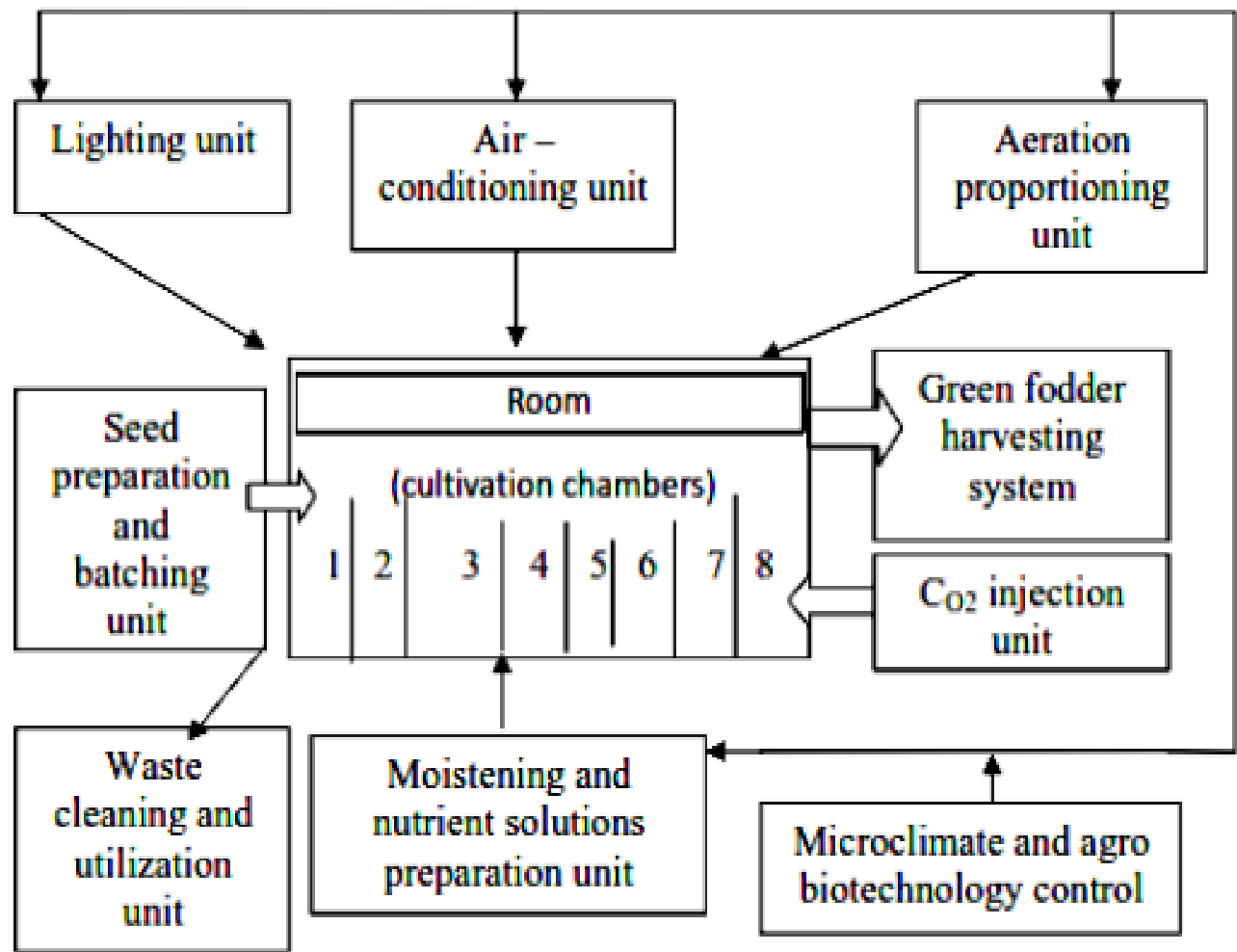

Fig. 1. Schematic diagram of the suggested hydroponic system

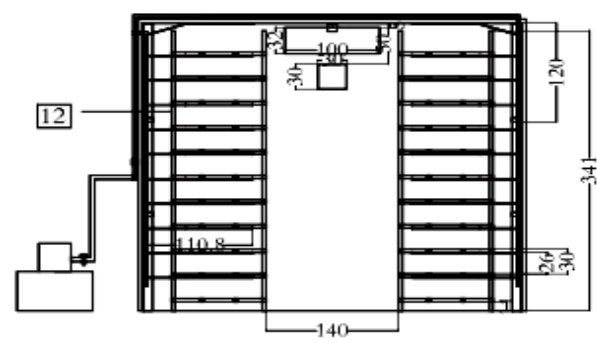

ELEV

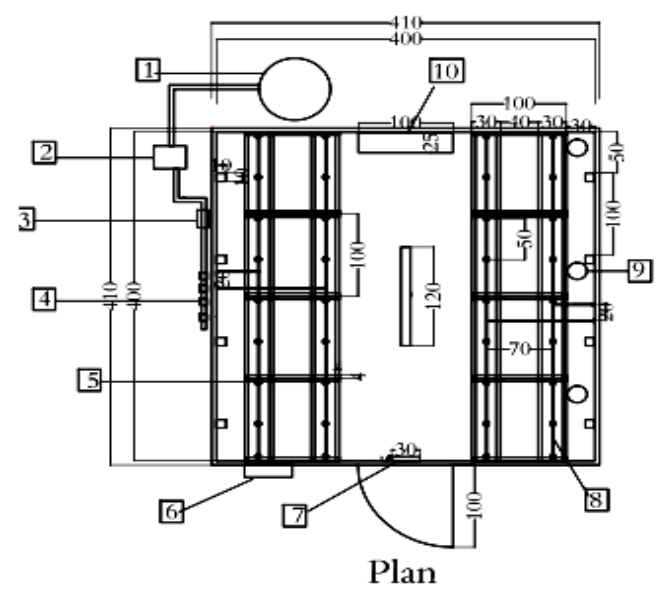

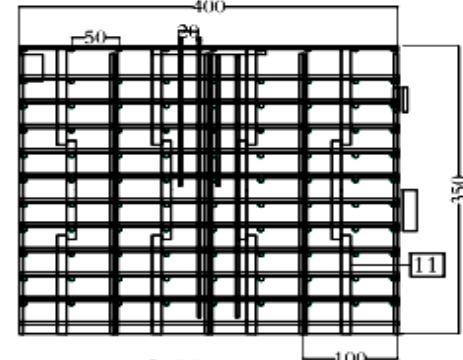

S.V

\begin{tabular}{|c|c|c|}
\hline No & Part name & No,Of \\
\hline 1 & Water storage tank & 1 \\
\hline 2 & Water pump & 1 \\
\hline 3 & inch disc filter & 1 \\
\hline 4 & PVC electric valves & 4 \\
\hline 5 & Mist sprayers with black nozzle & 396 \\
\hline 6 & Control unit & 1 \\
\hline 7 & Aeration unit & 1 \\
\hline 8 & Tube with 16 mm diameter & $200 \mathrm{~m}$ \\
\hline 9 & Drainage slot & 3 \\
\hline 10 & Air conditioner & 1 \\
\hline 11 & White fluorescent lamp & 25 \\
\hline 12 & Alumetal stand & 8 \\
\hline
\end{tabular}

All dimensions in, $\mathrm{cm}$

Fig. 2: The constructed hydroponic barley fodder unit 


\section{Stands}

Stands were created to carry the trays inside the unit. Each stand is made of a set of alumetal bars with thickness of $4 \times 4 \mathrm{~cm}$. The dimensions of each stand is $100 \times 100 \times 341 \mathrm{~cm}$, where each stand composed of 11 roles, height of each role is $30 \mathrm{~cm}$.

\section{Aeration unit}

An aeration unit was installed to provide oxygen to the system for plants growth. The process of aeration in the hydroponic barley fodder unit is important to maintain the proportion of oxygen gas and proportion of carbon dioxide inside the unit and to maintain the relative humidity of the air inside the unit so as not to cause any appearance of decay. The aeration unit consists of cooling fan of about $2400 \mathrm{rpm}$ with $25 \mathrm{~cm}$ diameter connected with control unit. The aeration unit delivers 5.2 $\mathrm{m}^{3} / \mathrm{min}$ of a fresh air to the chamber. The operating time of the aeration unit is controlled by timer controller with a capacity of 24 hours. It was placed on the top of the door of the unit at a height of 2.5 meters from the ground unit.

\section{Lighting unit}

The indoor lighting operating hours is conducted in the hydroponic system to conserve the fodder crop with lighting requirements. However, the lighting operating hours under the lighting intensity of 2000 lux were 16 hours/day. The lighting unit was designed to provide approximately 2000 lux meter of illumination per tray. This was achieved by 24 white fluorescent lamps (120 cm in length). The lambs have been installed on both sides of the unit, and controlled in operating time by controller timer with a capacity of 24 hours and accuracy of 30 minutes.

\section{Cooling unit}

A cooling unit was designed to continuously balance the air temperature, which produced by the lamps to avoid heating stresses of growing plants. The cooling unit is an air-conditioner with a capacity of $2.5 \mathrm{~kW}$ ( $3 \mathrm{hp}$ ). It was placed on the opposite side of the door of the unit at a height of 3 meters from the ground.

\section{Supplementary irrigation unit}

Water was added to each compartment as required to compensate water losses due to evaporation and water requirements for plants to complete its vital operations. The irrigation period under the same discharge for mist sprayer was $1 \mathrm{~min} / 2$ hours. However, the mist sprayer discharge was $47 \mathrm{l} / \mathrm{hr}$.

The water application unit consisted of the following parts:

- Water storage tank $1 \mathrm{~m}^{3}$ in size, for storing the water and nutrient solution.

- A pump with a power of $1.5 \mathrm{~kW}(2 \mathrm{hp})$ was placed beside the storage tank, with about $4800 \mathrm{1} / \mathrm{hr}$., flow rate at 3.6 bar operating pressure, to convey the water from the storage tank to the supplementary irrigation system. The pump was connected to the irrigation system using Polyethylene pipes of $32 \mathrm{~mm}$ outside diameter.

- A filter with $2.54 \mathrm{~cm}$ disc was put after the pump to purify water and prevent the entry of any impurities stuck in the water to sprinklers for preserving them and make sure that there is no blockage.

- Four PVC electric valves to control the amount of water fed to 396 mist sprayer and, for applying the water into the plant supporting trays. The timing and duration of opening/closing of the valves were controlled by an electronic circuit based on the investigated irrigation period.

- Irrigation control: ESP-4m, 4-station outdoor model controller with Features:(Three independent programs with 4 start times each for a total of 12 daily start times, Station run time: 0 minutes to 6 hours for all stations, 365day calendar with leap year intelligence means that it can be set an "Odd" or "Even" day watering schedule and not to be worry about changing the date on leap years and 5-year lithium battery maintains time and date during a power outage). Its electrical specifications input: $120 \mathrm{VAC} \pm 10 \%, 60 \mathrm{~Hz}$ Transformer output: 25.5 VAC 1A, with dimensions: Width: $27.2 \mathrm{~cm}$, Height: $19.5 \mathrm{~cm}$ and Depth: $11.2 \mathrm{~cm}$. 
- 396 mist sprayer with black nozzle, with 47 $1 / \mathrm{hr}$., discharge at 3 bar operating pressure, and $2 \mathrm{~m}$ covered radius attached to $16 \mathrm{~mm}$ tubes at $50 \times 70 \mathrm{~cm}$ spacing. Its uniformity coefficient is $94 \%$.

\section{$\mathrm{CO}_{2}$ injection unit}

The $\mathrm{CO}_{2}$ injection unit was used with a concentration of $10 \mathrm{~min} / 2$ hours to supply the seeds of their own needs in order to raise value of the final product. The $\mathrm{CO}_{2}$ injection unit consists of feeding bottle from $\mathrm{CaCO}_{3}$ and bottle from $\mathrm{HCl}$ to produce $\mathrm{CO}_{2}$ through $32 \mathrm{~mm}$ pipe diameter inside the growth room.

\section{Drainage unit}

The drainage unit is 3 slots placed in the right side of the hydroponic unit and connected with 4 inches polyethylene tube to collect the drainage water and deliver it to the external tank.

\section{Micro-climate and agro-biotechnology control system \\ Micro-climate and agro-biotechnology system consists of two main units:}

\section{The temperature unit}

The hydroponic barley fodder temperature system has a significant impact on the process of breeding that showing its impact on product quantity and quality. Therefore, one temperature of $20{ }^{\circ} \mathrm{C}$ was tested as the barley is grown in the winter and needs to be at low temperature to conserve the appropriate micro-climate environment of the cultivated barley under the hydroponic system. It consists of gauge capacity of about $40{ }^{\circ} \mathrm{C}$, with an accuracy of about $2{ }^{\circ} \mathrm{C}$ and sensor electrode to measure the temperature inside the growth room.

\section{The nutrient solution unit}

Nutrient solution was used with a concentration of $1 \mathrm{~cm}^{3} / 1$ to supply the seeds of their own needs of nutrients in order to raise the nutritional value of the final product. Inorganic nutrient solution (control) developed by (ElBehairy, 1994) was used. However, it consists of: N 259.6, P 35, K 300, Ca 160.2, Mg 50, S 221, Fe 5, Mn 1, B 0.3, Cu 0.1, Mo 0.1, and Zn 0.1 as ppm. The electrical conductivity (EC) of the nutrient solution was maintained between
0.31-0.33 mmhos $\mathrm{cm}^{-1}$ and the $\mathrm{pH}$ was maintained in a range of about 7.0-7.2 by using citric acid for all-organic solutions. On the other hand, the nutrient solution volume was adjusted once a day by adding tap water up to recognized mark level in the tank. The amount of water was measured and recorded for calculation of water consumptive use. The nutrient solutions were completely refreshed every day.

\section{The used crop}

Barley seeds (Giza, 127), was used in this study. The seeds were sown on 24 hours and transplanted on prototype to determine the percentage of germination. Pre-soaking is important as there is a rapid uptake of water which facilitates the metabolism of reserve material and the utilization of these reserves for growth and development. Because of that, the seeds had been soaked for 12 hours before the introduction of the unit. Seed density of 1050 grams per unit area of about $(30 \times 70 \mathrm{~cm})$ had been evaluated.

\section{Methods}

\section{Experimental Procedure and Treatments}

To evaluate the constructed hydroponic unit, the following technical parameters and its associated treatments had been considered:

- Four aeration rates of 1, 2, 3 and $4 \mathrm{hr}$./day.

- Four growing periods of 5, 6, 7 and 8 days

- Two conditions of with and without nutrient solution addition.

- Two conditions of with and without $\mathrm{CO}_{2}$ injection

\section{Measurements and determinations}

The performance of the hydroponic unit was evaluated taking into consideration the following indicators:

\section{Plant measurements}

Total barley yield as well as yield quality were measured for the final product at the end of the growing period.

\section{Total yield}

Total yield $(\mathrm{kg} /$ period $)$ was measured as follows: 
Total yield $=$ fresh growth yield + fresh root yield (1)

\section{Yield quality}

Yield quality was measured in terms of moisture content, dry matter and protein ratio as follows:

\section{Moisture content (M.C)}

MC (\%) $=100$ (Fresh mass - Dry mass)/ Fresh mass ....... (2)

\section{Dry matter (DM)}

DM $(\%)=100($ Dry mass / Fresh mass $)$

\section{Protein percentage (\%)}

Protein can be calculated by the following equation: Adapted and modified by Merrill and Watt (1973):

Protein $(\%)=\mathrm{N}(\%) \times 5.83$

\section{Water use efficiency}

Water use efficiency was calculated according to Jensen (1983) as follows:

WUE $(\mathrm{gm} / \mathrm{l})=\frac{\text { Barley yield }\left(\mathrm{g} / \mathrm{cm}^{2}\right)}{\text { Amount of applied irrigation water }\left(1 / \mathrm{cm}^{2}\right)} \ldots$

\section{Energy requirements}

Energy requirements can be calculated by the following equation:

Energy requirements $(\mathrm{kW}$.period $/ \mathrm{kg})=\frac{\text { Required power }(\mathrm{kW})}{\text { Total yield }(\mathrm{kg} / \text { period })} \ldots(6)$

Required power was determined as follows:

$\mathrm{P}=\mathrm{I} \times \mathrm{V} \times \cos \theta$

Where

$\mathrm{P}$ - required power, $\mathrm{kW}$,

I - current strength, ampere,

$\mathrm{V}$ - Voltage, volt, being equal to $220 \mathrm{~V}$

$\cos \theta$ - power factor, being equal to 0.66

\section{Economic evaluation}

The net profit of barley yield was calculated by using the following formula (Younis et al., 1991):

$\mathrm{P}=(\mathrm{Yt} \times \mathrm{d})-\mathrm{Ct} \ldots \ldots(8)$

Where:

$P$ - Net profit, LE/period
Yt - Total barley yield, kg/period

d - Yield price, $\mathrm{LE} / \mathrm{Kg}$

$\mathrm{Ct}$ - Total period cost, LE/period

Period cost was determined as follows:

Period cost $(\mathrm{LE} /$ period $)=$ Hourly cost $(\mathrm{LE} / \mathrm{hr}$. Period (hr./period)

Hourly cost was determined using conventional method of estimating both fixed and variable costs.

\section{RESULTS AND DISCUSSION}

The discussion will cover the obtained results under the following heads:

\section{Effect of Some Parameters on Barley Yield and Yield Quality}

Aeration rate as well as growing period, $\mathrm{CO}_{2}$ injection and nutrient solution addition has a great effect on barley yield and yield quality (Figs. 3, 4 and 5).

\section{Effect of aeration rate}

Representative total yield, protein percentage, dry matter percentage and moisture content versus aeration rate are given through various growing periods under conditions of $\mathrm{CO}_{2}$ injection and nutrient solution addition in Fig. 3.

Concerning the effect of aeration rate on total yield, results show that increasing aeration rate from 1.0 to $2.0 \mathrm{hr}$./day, increased total yield from 2316.6 to 2379.3 , from 2985.84 to 3029.4 , from 3670.59 to 3770.3 and from 4572.48 to $4626.4 \mathrm{~kg} /$ period for growing periods of $5,6,7$ and 8 days, respectively. Any further increase in aeration rate from 2.0 up to $4.0 \mathrm{hr}$./day, decreased total yield from 2379.3 to 2102.1, from 3029.4 to 2680.92 , from 3770.3 to 3312.54 and from 4626.4 to $3991.68 \mathrm{Kg} /$ period under the same mentioned conditions. The decrease of total yield by increasing aeration rate from 2.0 to $4.0 \mathrm{hr}$./day is attributed to the instability of the temperature, which leads to rotting of the roots.

Relating to the effect of aeration rate on protein percentage, the obtained results show that increasing aeration rate from 1.0 to 4.0 $\mathrm{hr} . /$ day, decreased protein percentage from 18.29 to 16.91 , from 17.93 to 16.57 , from 17.54 to 16.22 and from 17.21 to $15.93 \%$ for growing periods of 5, 6, 7 and 8 days. 

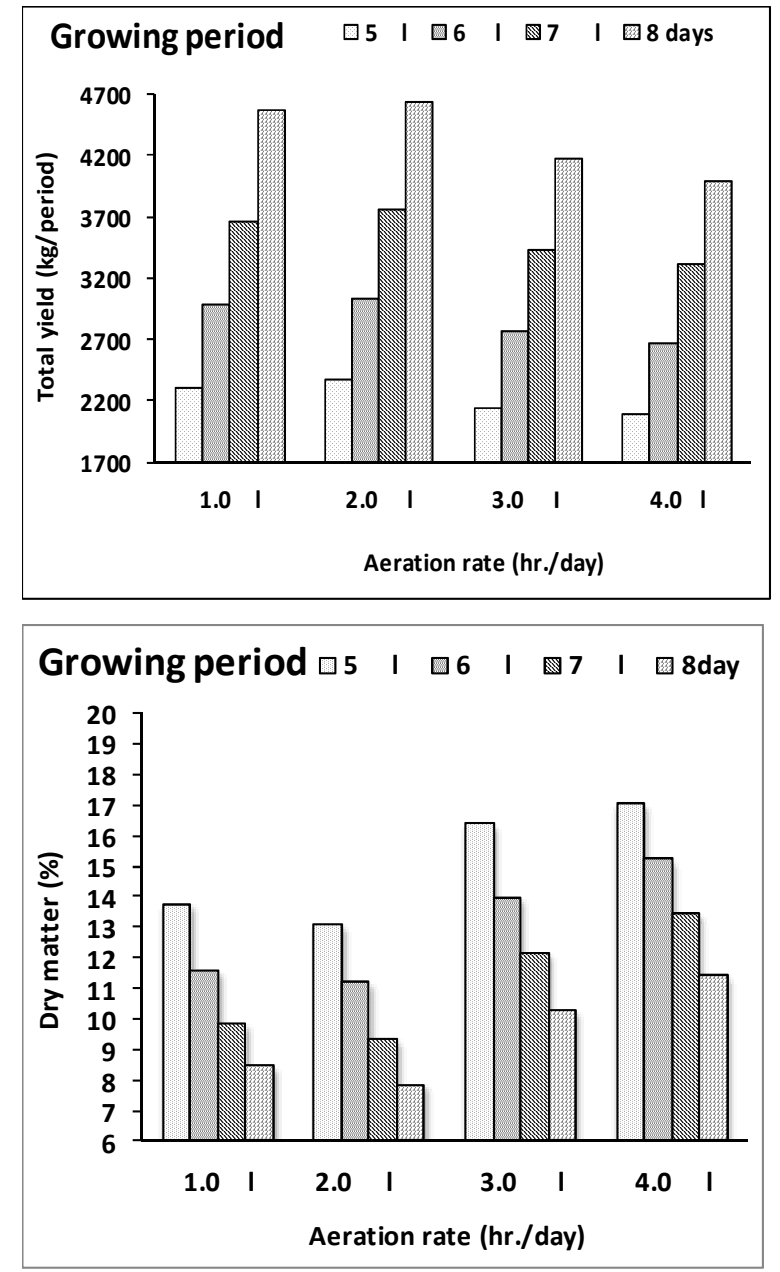
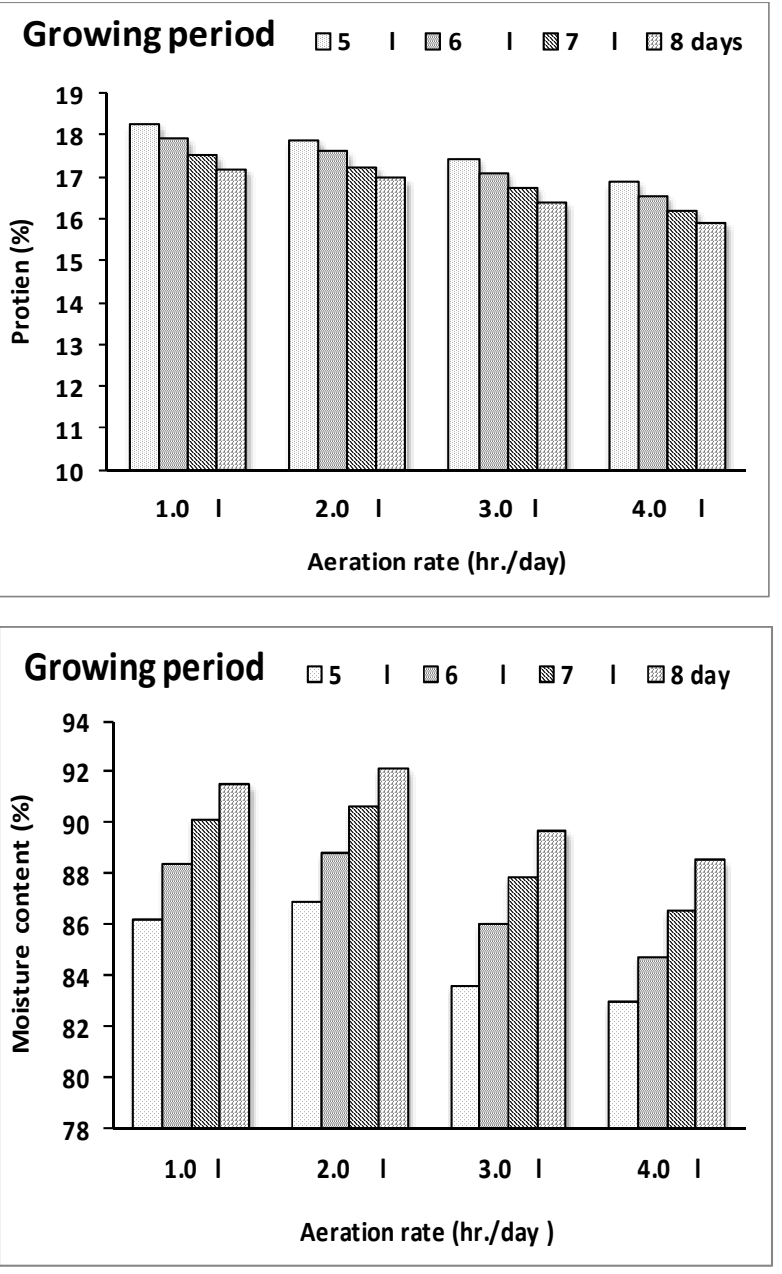

Fig. 3: Effect of aeration rate on total yield and yield quality

The increase in protein percentage by decreasing aeration rate is due to the decrease in dry weight, particularly carbohydrates, through respiration during germination. Higher germination temperature and longer sprouting time means greater losses in dry weight and increases in protein content. These findings are in agreement with those indicated by Chavan and Kadam (1989)

Considering the effect of aeration rate on dry matter, results show that increasing aeration rate from 1.0 to $4.0 \mathrm{hr}$./day, increased dry matter percentage from 13.79 to 17.05 , from 11.6 to 15.26, from 9.86 to 13.46 and from 8.47 to $11.48 \%$ for growing periods of $5,6,7$ and 8 days.

The increase in dry matter percentage by increasing aeration rate is attributed to that the photosynthesis is not important for the metabolism of the seedling until, when the chloroplasts are activated, and this may be reflected into dry matter losses due to respiration and the negligible amount of photosynthesis by young seedling at the low growing days. The above-mentioned results are in agreement with those had been observed by Chavan and Kadam (1989).

As to the effect of aeration rate on moisture content, results showed that increasing aeration rate from 1.0 to $2.0 \mathrm{hr}$./day, increased moisture content from 86.21 to 86.87 , from 88.4 to 88.79 , from 90.14 to 90.65 and from 91.53 to $92.13 \%$ for growing periods of 5, 6, 7 and 8 days. Any further increase in aeration rate from 2.0 up to $4.0 \mathrm{hr}$./day, decreased moisture content from 86.87 to 82.95 , from 88.79 to 84.74 , from 90.65 to 86.54 and from 92.13 to $88.52 \%$ under the same mentioned growing periods. 
The decrease of total yield by increasing aeration rate from 2.0 to $4.0 \mathrm{hr}$./day is attributed to low dry matter resulting in high moisture content.

\section{Effect of $\mathrm{CO}_{2}$ injection}

Representative total yield, protein percentage, dry matter percentage and moisture content versus $\mathrm{CO}_{2}$ injection are given through various growing periods under conditions of $2 \mathrm{hr} /$ day aeration rate and nutrient solution addition in Fig. 4.

Concerning the effect of $\mathrm{CO}_{2}$ injection on total yield, results show $\mathrm{CO}_{2}$ injection increased total yield from 2049.3 to 2316.6 , from 2646.07 to 2985.84 , from 3355.04 to 3670.59 , and from 4213.44 to $4572.48 \mathrm{~kg} /$ period for growing periods of $5,6,7$ and 8 days, respectively compared to without $\mathrm{CO}_{2}$ injection. The increase of total yield in case of with $\mathrm{CO}_{2}$ injection may be attributed to that the amount of carbon dioxide has increased from an ambient level of 300 PPM to a high level of 2000 PPM, the amount which a plant can process if in full sunlight. So $\mathrm{CO}_{2}$ injection into the fodder shed cuts the growing time of malt barley from 7 days to 4 days therefore increasing the shed production output by $75 \%$.

Relating to the effect of $\mathrm{CO}_{2}$ injection on protein percentage, the obtained results show. That $\mathrm{CO}_{2}$ injection increased protein percentage from 15.67 to 18.29 , from 15.23 to 17.93 , from 14.85 to 17.54 and from 14.48 to $17.21 \%$ for growing periods of 5, 6, 7 and 8 days compared to without $\mathrm{CO}_{2}$ injection.

Considering the effect of $\mathrm{CO}_{2}$ injection on dry matter percentage, results showed that $\mathrm{CO}_{2}$ injection increased dry matter percentage from 13.79 to 17.7 , from 11.6 to 15.57 , from 9.86 to 13.1 and from 8.47 to $9.88 \%$ for growing periods of 5, 6, 7 and 8 days, respectively compared to without $\mathrm{CO}_{2}$ injection. This attributed to that all plant dry matter is about $90 \%$ carbon, hydrogen and oxygen. All the carbon has to come from the carbon dioxide $\left(\mathrm{CO}_{2}\right)$ in the air. The mentioned results are in agreement with that had been observed by Reinders (1996).

As to the effect of $\mathrm{CO}_{2}$ injection on moisture content, results showed that $\mathrm{CO}_{2}$ injection increased moisture content from 82.3 to 86.21 , from 84.43 to 88.4 , from 86.9 to 90.14 and from 90.12 to $91.53 \%$ for growing periods of $5,6,7$ and 8 days, respectively compared to without $\mathrm{CO}_{2}$ injection.

\section{Effect of nutrient solution addition}

Representative total yield, protein percentage, dry matter percentage and moisture content versus nutrient solution addition are given through various growing periods under conditions of $2 \mathrm{hr}$./day aeration rate and $\mathrm{CO}_{2}$ injection solution addition in Fig. 5.

Concerning the effect of nutrient solution addition on total yield, results showed that nutrient solution addition increased total yield from 2065.8 to 2316.6, from 2657.16 to 2985.84, from 3291.75 to 3670.59 and from 3949.44 to $4572.48 \mathrm{~kg} /$ period for growing periods of $5,6,7$ and 8 days, respectively compared to without nutrient solution addition. The decrease of total yield in case of without nutrient solution addition is attributed to that the plants require 17 essential elements for their growth and development. Without these nutrients, plants cannot complete their life cycles and growth cannot be replaced by any other elements.

Relating to the effect of nutrient solution addition on protein percentage, the obtained results showed that nutrient solution addition increased protein percentage from 14.36 to 18.29 , from 14.03 to 17.93 , from 13.81 to 17.54 and from 13.52 to $17.21 \%$ for growing periods of $5,6,7$ and 8 days, respectively compared to without nutrient solution addition.

Considering the effect of nutrient solution addition on dry matter percentage, results showed that nutrient solution addition increased dry matter percentage from 13.79 to 17.35 , from 11.6 to 15.47 , from 9.86 to 13.67 and from 8.47 to $11.88 \%$ for growing periods of 5, 6, 7 and 8 days, respectively compared to without nutrient solution addition.

As to the effect of nutrient solution addition on moisture content, results showed that nutrient solution addition decreased moisture content from 86.21 to 82.65 , from 88.4 to 84.53 , from 90.14 to 86.33 and from 91.53 to $88.12 \%$ for growing periods of $5,6,7$ and 8 days, respectively compared to without nutrient solution addition. 
Zagazig J. Agric. Res., Vol. 44 No. (3) 2017
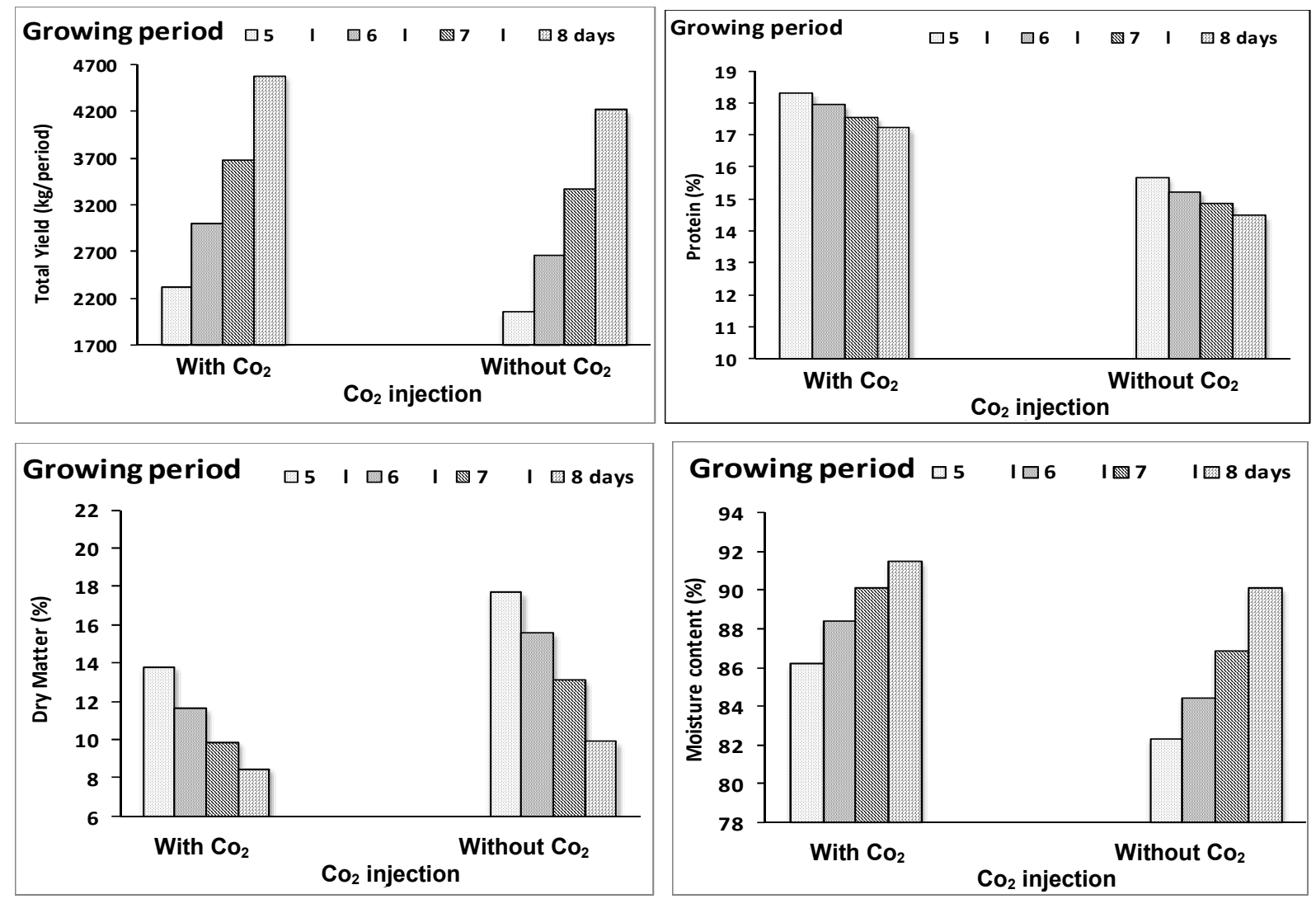

Fig. 4: Effect of $\mathrm{CO}_{2}$ injection on total yield and yield quality
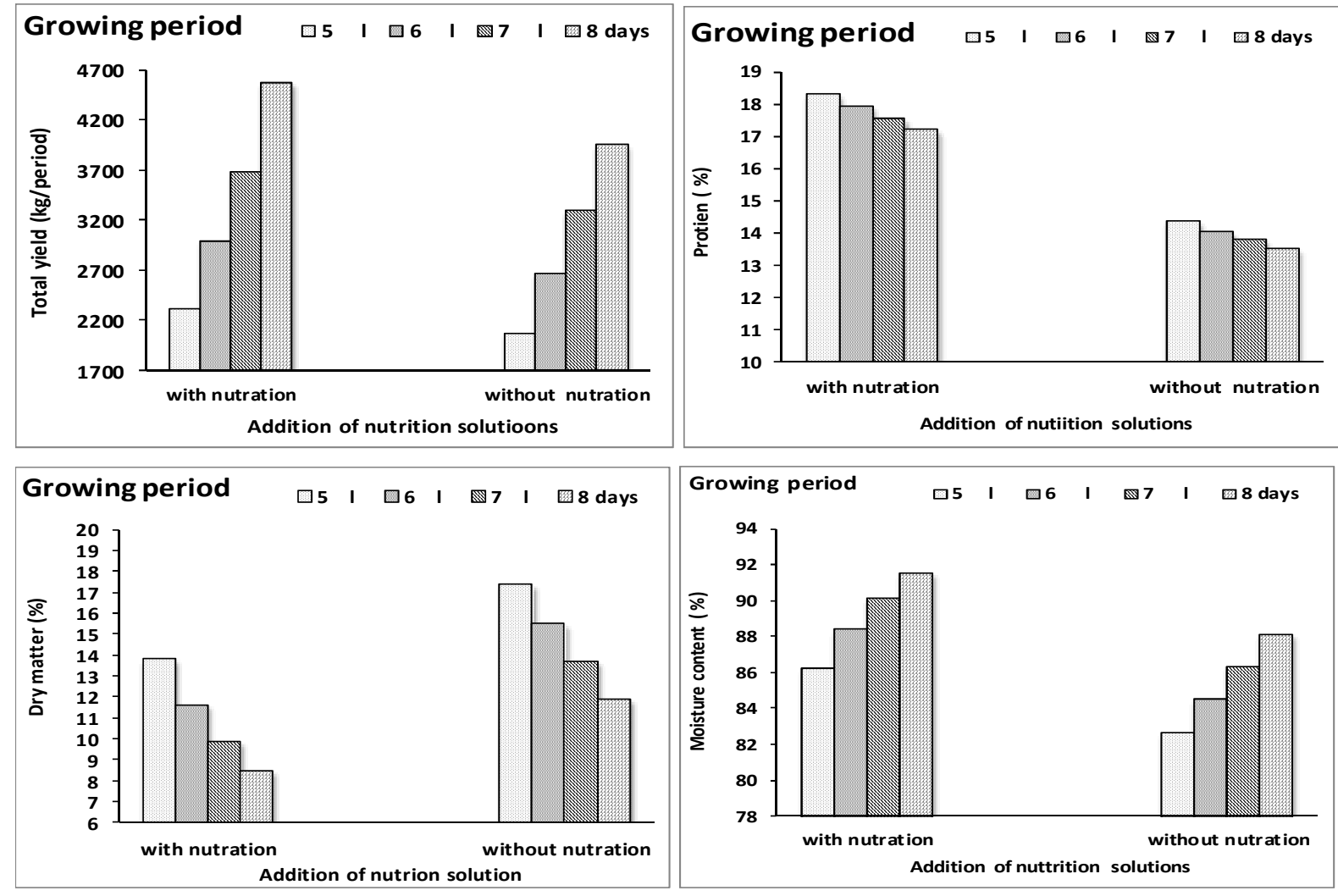

Fig. 5. Effect of nutrient solution addition on total yield and yield quality 


\section{Effect of Some Parameters on Water Use Efficiency}

Aeration rate as well as $\mathrm{CO}_{2}$ injection and nutrient solution addition affected water use efficiency (WUE) as shown in Fig. 6.

\section{Effect of aeration rate}

Results showed that increasing aeration rate from 1.0 to $2.0 \mathrm{hr}$./day, increased WUE from 124.468 to 127.836 , from 133.687 to135.634, from 140.868 to 144.858 and from 153.546 to $156.028 \mathrm{~g} / \mathrm{l}$ for growing periods of 5, 6, 7 and 8 days, respectively. Any further increase in aeration rate from 2.0 up to $4.0 \mathrm{hr}$./day, decreased WUE from 127.836 to 112.943 , from 135.634 to 120.035 , from 144.858 to 127.127 and from 156.028 to $134.042 \mathrm{~g} / 1$ under the same mentioned conditions. The decrease of WUE by increasing aeration rate from 2.0 to $4.0 \mathrm{hr}$./day is attributed to the decrease of the yield.

\section{Effect of $\mathrm{CO}_{2}$ injection}

Results showed that $\mathrm{CO}_{2}$ injection increased WUE from 110.106 to 124.468 , from 118.475 to 133.687 , from 128.758 to 140.868 and from 141.486 to $153.546 \mathrm{~g} / 1$ for growing periods of 5 , 6,7 and 8 days, respectively compared to without $\mathrm{CO}_{2}$ injection.

\section{Effect of nutrient solution addition}

Results showed that nutrient solution addition increased WUE from110.992 to 124.468, from 118.971 to 133.687 , from 126.329 to 140.868 , and from 132.624 to $153.546 \mathrm{~g} / 1$ for growing periods of 5, 6, 7 and 8 days, respectively compared to without nutrient solution addition. This attributed to the direct relationship between the total yield and the WUE, without nutrient solution addition, lower total yield is obtained that reduced WUE, as shown in Fig. 6.

\section{Effect of Aeration Rate on Energy Requirements}

Increasing aeration rate increased the required power resulting in an increase in the energy requirements as shown in Fig. 7.

Results showed that increasing aeration rate from 1.0 to $4.0 \mathrm{hr}$./day, increased energy requirements from 180.15 to 181 , from 216.18 to 217.1 , from 252.12 to 253 and from 288.24 to
$289.03 \mathrm{~kW}$ - Period $/ \mathrm{kg}$ for growing periods of 5 , 6, 7 and 8 days, respectively. The increase in energy requirements by increasing both aeration rate and growing period is attributed to the more power required for operating the cooling fan.

\section{Period Cost and Net Profit}

Aeration rate as well as $\mathrm{CO}_{2}$ injection and nutrient solution addition affected both period cost and net profit as shown in Fig. 8.

\section{Effect of aeration rate}

Considering the effect of aeration rate on period cost, results showed that increasing aeration rate from 1.0 to $4.0 \mathrm{hr}$./day, increased period cost from 2092.5 to 2115.0 , from 2511.0 to 2538.0, from 2929.5 to 2961.0 and from 3348.0 to $3384.0 \mathrm{LE} /$ period for growing periods of 5, 6, 7 and 8 days, respectively. The increase of period cost by increasing aeration rate is attributed to the more power required for operating the unit.

Relating to the effect of aeration rate on net profit, results show that increasing aeration rate from 1.0 to $4.0 \mathrm{hr}$./day, decreased net profit from 3699 to 3140.25 , from 4953.6 to 4164.3 , from 6247 to 5320.35 and from 8083.20 to $6595.20 \mathrm{LE} /$ period for growing periods of 5, 6, 7 and 8 days respectively. The decrease of net profit by increasing aeration rate is attributed to the low obtained total yield.

\section{Effect of $\mathrm{CO}_{2}$ injection}

With regard to the effect of $\mathrm{CO}_{2}$ injection on period cost, results showed that $\mathrm{CO}_{2}$ injection increased period cost from 1990.0 to 2100.0 , from 2488.0 to 2520.0 , from 2786.0 to 2940.0 and from 3184.0 to $3360.0 \mathrm{LE} /$ period for growing periods of $5,6,7$ and 8 days respectively compared to without $\mathrm{CO}_{2}$ injection.

As to the effect of $\mathrm{CO}_{2}$ injection on net profit, results showed that $\mathrm{CO}_{2}$ injection increased net profit from 3442.63 to 3848.25 , from 4397.45 to 5053.5 , from 5772.55 to 6496.35 and from 7455.20 to $8256 \mathrm{LE} /$ period for growing periods of $5,6,7$ and 8 days, respectively compared to without $\mathrm{CO}_{2}$ injection.

\section{Effect of nutrient solution addition}

Regarding the effect of nutrient solution addition on period cost, results showed that nutrient solution addition increased period cost from 2002.5 to 2100.0 , from 2475.0 to 2520.0 , from 2887.5.0 to 2940.0 and from 3300.0 to 
Zagazig J. Agric. Res., Vol. 44 No. (3) 2017
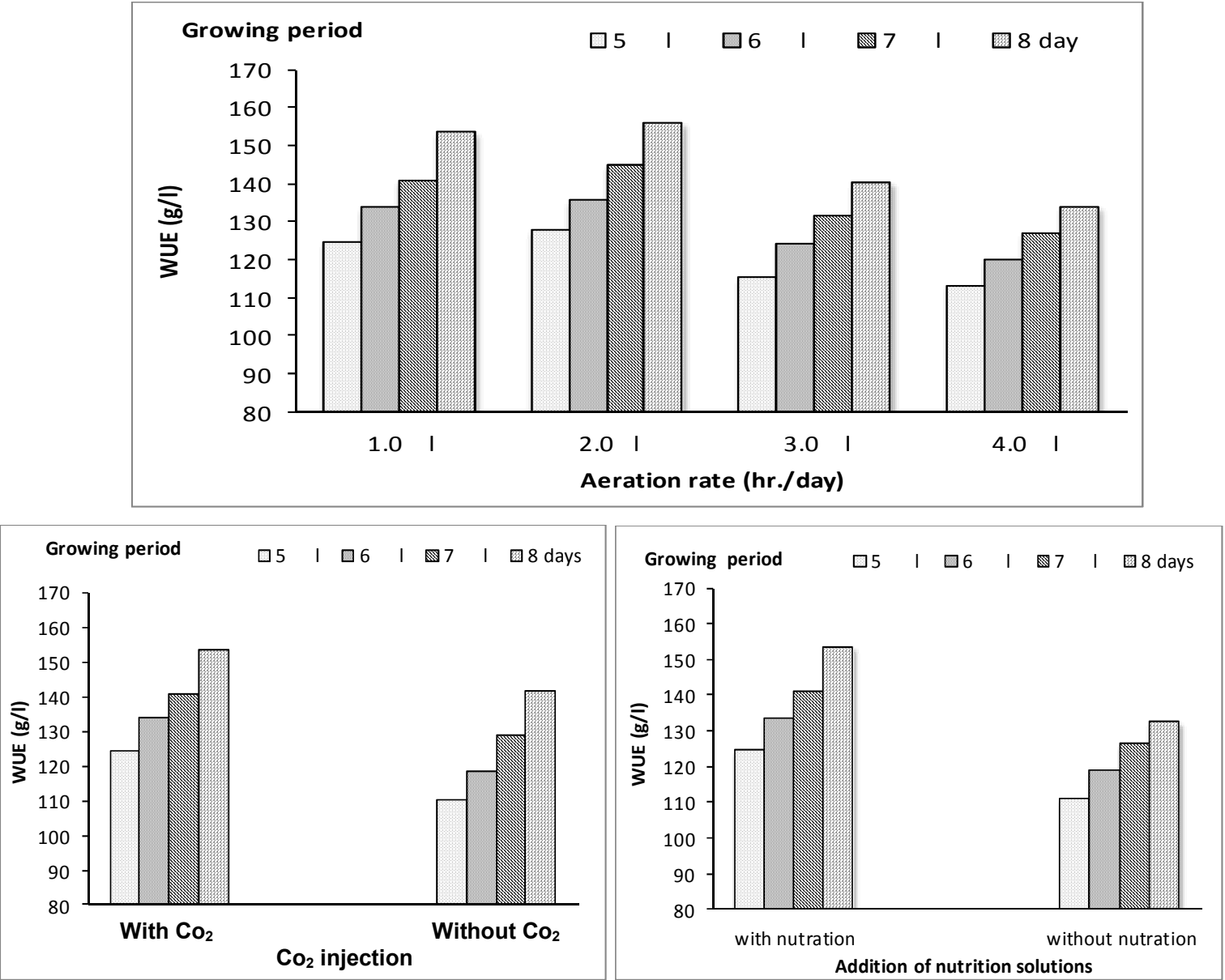

Fig. 6. Effect of some technical parameters on water use efficiency

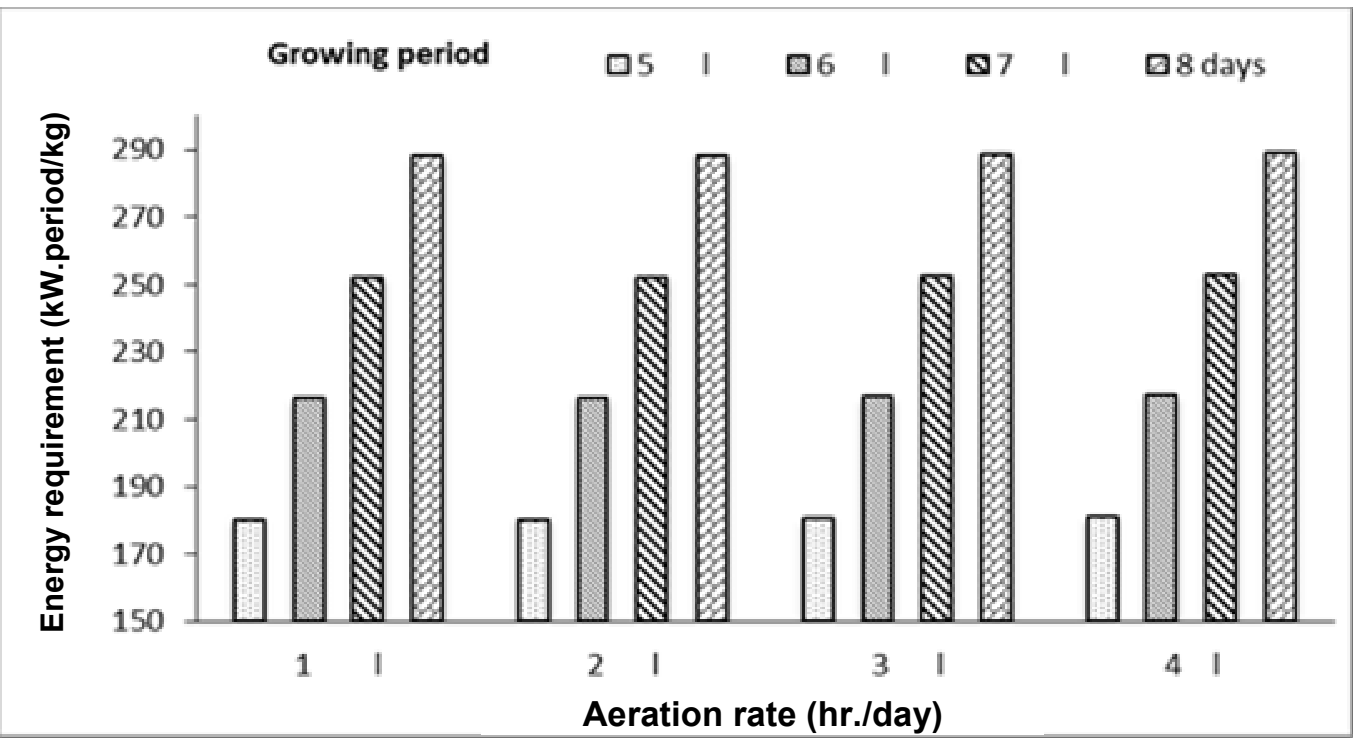

Fig. 7. Effect of aeration rate on energy requirements 

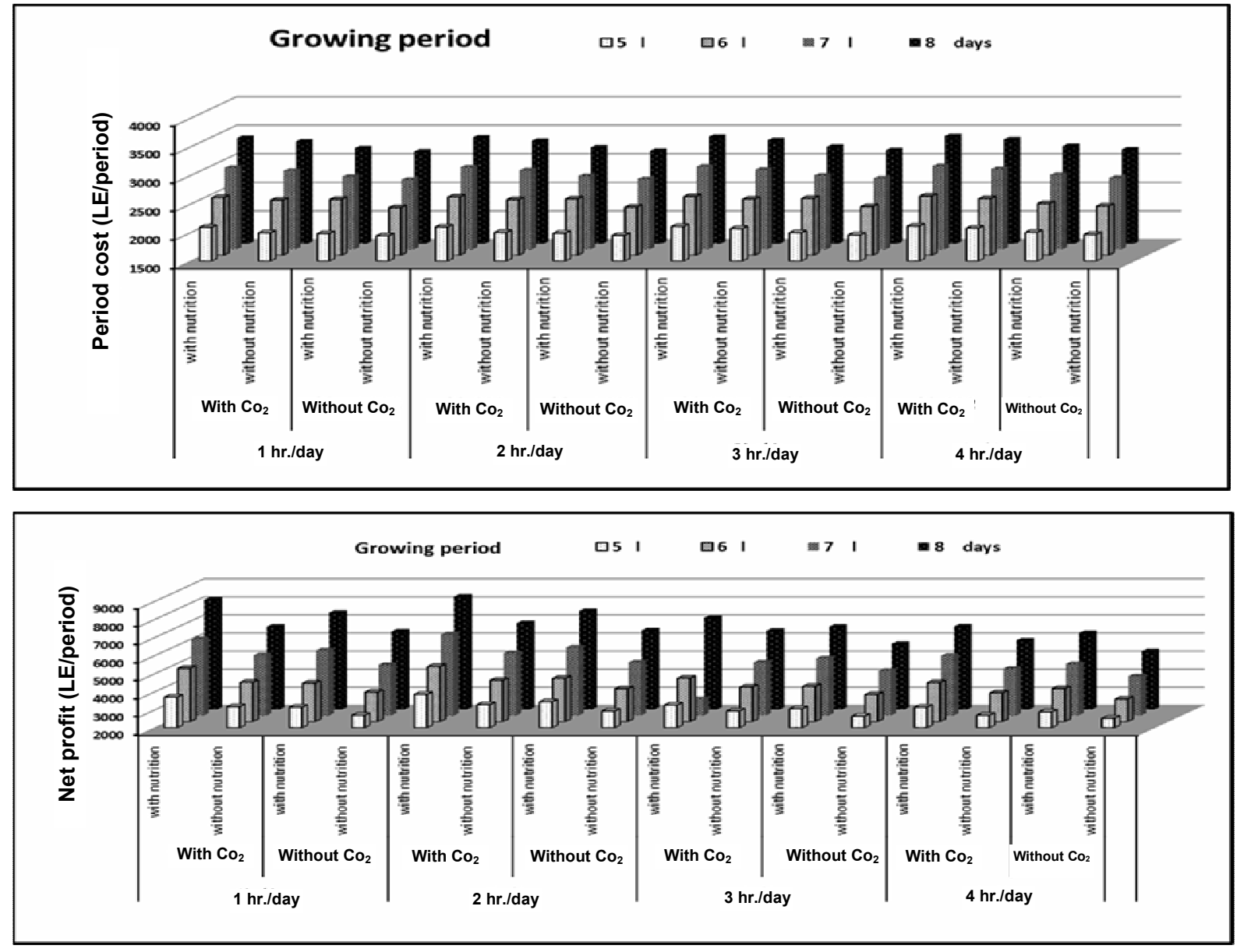

Fig. 8. Effect of different parameters on period cost and net profit

$3360.0 \mathrm{LE} /$ period for growing periods of 5, 6, 7 and 8 days, respectively compared to without nutrient solution addition.

Referring to the effect of nutrient solution addition on net profit, results showed that nutrient solution addition increased net profit from 3285.75 to 3848.25 , from 4296.6 to 5053.5 , from 5463.15 to 6496.35 and from 6784.8 to $8256 \mathrm{LE} /$ period for growing periods of $5,6,7$ and 8 days, respectively compared to without nutrient solution addition.

\section{Conclusion}

The experimental results reveal that total yield (4646.4 kg/period), plant moisture content $(2.13 \%)$, water use efficiency $(56.028 \mathrm{~g} / \mathrm{l})$ and net profit ( $8256 \mathrm{LE} /$ period) were in the optimum region under conditions of 8 days growing period, $2 \mathrm{hr}$./day aeration rate, with both nutrient solution addition and $\mathrm{CO}_{2}$ injection. While the optimum region of protein percentage (18.29\%) was optimum under conditions of 5.0 days growing period, $1 \mathrm{hr}$./day aeration rate, with both nutrient solution addition and $\mathrm{CO}_{2}$ injection. Meanwhile the optimum region of dry matter (21.12\%) was optimum under conditions of 5 days growing period, $2 \mathrm{hr}$./day aeration rate, without neither both nutrient solution addition nor $\mathrm{CO}_{2}$ injection.

\section{REFERENCES}

Cader, B. (2002). Simple Shed Company, Morayfield, Queensland, Australia.

El-Behairy, U. A. (1994). The effect of levels of phosphorus and zinc in the nutrient solution on macro and micro nutrient uptake and translocation in cucumber (Cucumis sativus 
L.) grown by the Nutrient Film Technique. $\mathrm{Ph}$. D. Univ., London, Wye College England.

Chavan, J. and S.S. Kadam (1989). Nutritional improvement of cereals by sprouting. Critical Rev. Food Sci. and Nut., 28 (5): 401-437.

Jensen, M.E. (1983). Design and operation of farm irrigation systems. Ame. Soc. Agric. Eng., Michigan. USA, 827.

Jensen, M.H. (1999). Hydroponics Worldwide In: Proceedings International Symposium on Growing Media and Hydroponics, Ontario, Canada 19-26 May 1997, Ed. AP Papadopoulos. Acta Hort., 481: 719-729

Merrill, A. L. and B.K. Watt (1973). Energy Value of Foods, Basis and Derivation (Revision). Agric. Handbook No. 74. US Agric. Dept., Washington, DC.

Morgan, J., R.R. Hunter and R. O'Haire (2002). Limiting Factors in hydroponic barley grass production. $8^{\text {th }}$ Int. Cong. on Soilless Cult. Hunter's Rest; South Africa.

Reinders, G. (1996). 'How to super charge your garden'. Mainly Puble., British Columbia: 30.

Rotar, P. (2004). Hydroponic techniques sprout healthy, inexpensive fodder. Accessed through [http://www. isar.org/ pubs/ST/ hydroponics $47 . \mathrm{html}]$.

Seymour, G. (1993). Review of Commercial Hydroponic Crop Production Systems in: Commercial Hydroponics in Australasia, a Guide for Growers, Pro-Set Pty Ltd, Hobart.

Wang, H.X., C.M. Liu and L. Zhang (2002). Water-saving agriculture in China: an overview. Adv. in Agron., 75: 135-171.

Younis, S.M., A.M. Shaiboon and A.O. Aref (1991). Evaluation of some mechanization methods of rice production in Egypt. Misr J. Ag. Eng., 8 (1): 39 - 49.

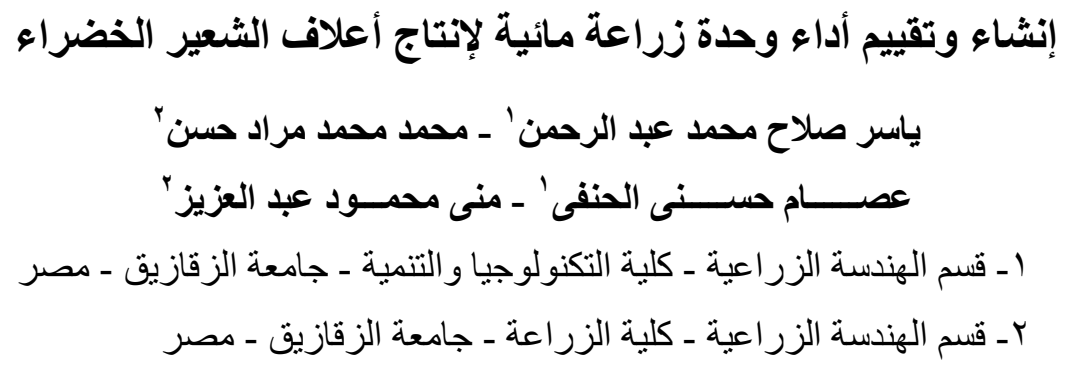

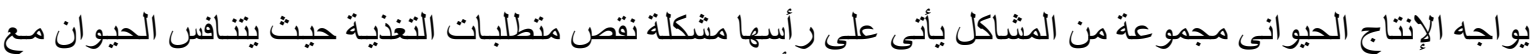

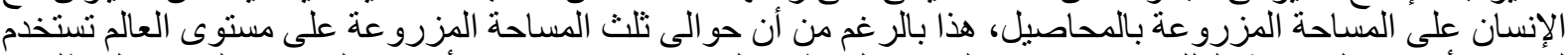

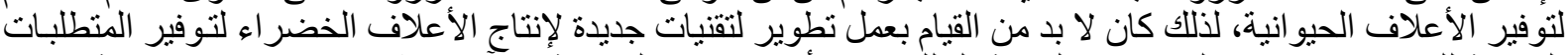

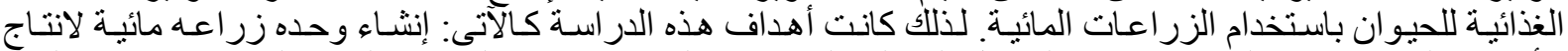

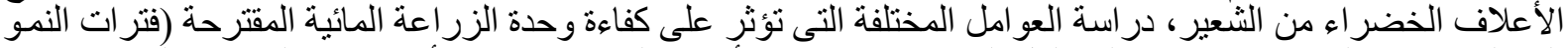

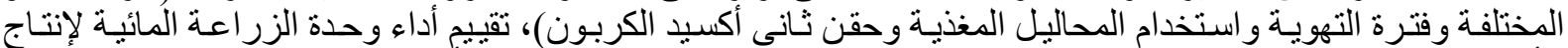

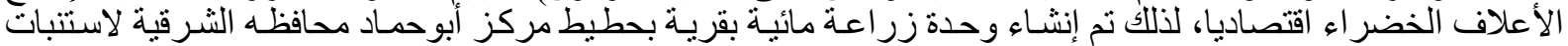

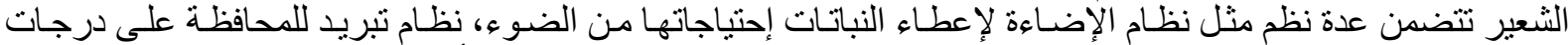

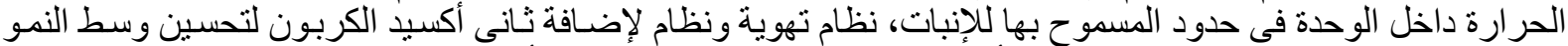

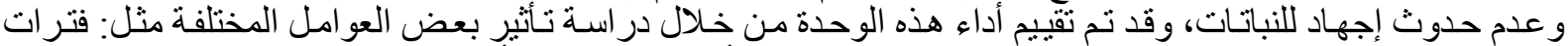

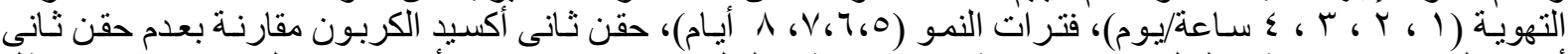

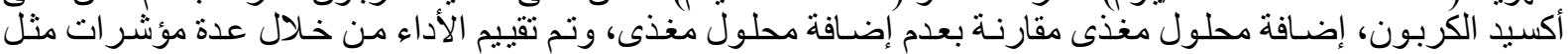

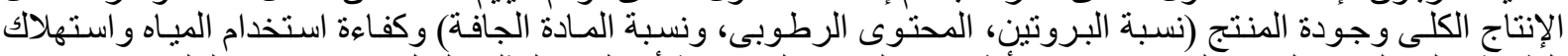

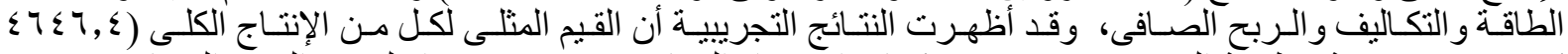

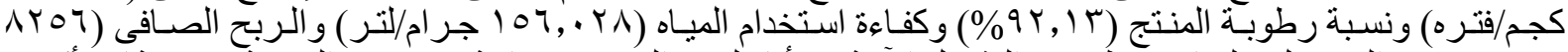

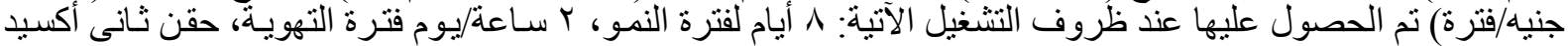

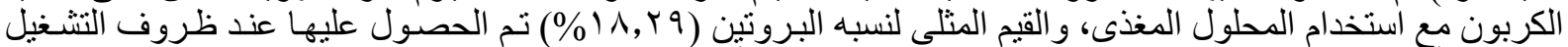

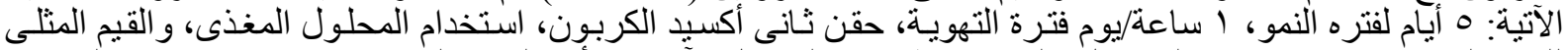

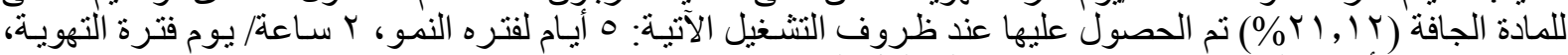

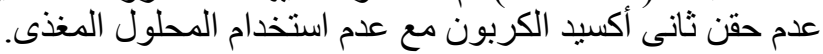

أستاذ الهندسة الزر اعية المتفرغ - كلية الزر اعة - جامعة المنصورة.

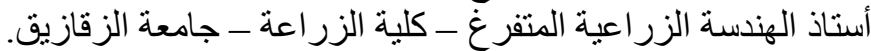

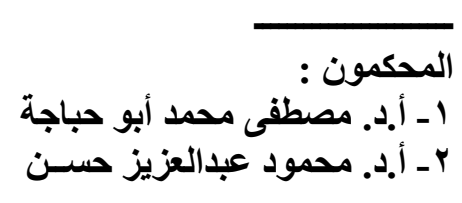

